\title{
Ecthyma gangrenosum in a case of acute lymphoblastic lymphoma
}

\author{
Kundan Mishra, Uday Yanamandra, Gaurav Prakash, Pankaj Malhotra
}

Department of Internal Medicine (Clinical Hematology Division), Post Graduate Institute of Medical Education and Research, Chandigarh, India

\section{Correspondence to Dr U Yanamandra, udayj2@gmail.com}

Accepted 14 December 2016
CrossMark

\section{To cite: Mishra K,}

Yanamandra U, Prakash G, et al. BMJ Case Rep

Published online: [please include Day Month Year] doi:10.1136/bcr-2016218501

\section{DESCRIPTION}

A 14 year-old-girl, a recently diagnosed case of pre-B acute lymphoblastic leukaemia (on modified BFM-90 protocol, week 2), presented with septic shock (heart rate, 124/min; blood pressure, 70/ $40 \mathrm{~mm} \mathrm{Hg}$ ) and swelling on the left side of face with necrotic ulcer, local induration and tenderness (figure 1A) of 2 days duration suggestive of ecthyma gangrenosum. Cultures from skin scraping, biopsy and peripheral blood revealed Pseudomonas aeruginosa. Evaluation for mucormycosis (fungal culture and histology of skin/nasal scrapings) was negative. She was promptly treated with empirical antibiotics and antifungals, later tailored per sensitivity (intravenous imipenem, intravenous amikacin). Her situation initially worsened during the first $48 \mathrm{~h}$ (figure 1B) but subsequently recovered in 2 weeks (figure 1C, D).

Ecthyma gangrenosum is a rapidly progressive infection of axilla, groin, buttocks or groin; however, involvement of the face is rare. ${ }^{1}$ It is often seen in immunocompromised individuals (leukaemia, lymphoma, postchemotherapy, severe burns, severe malnutrition, etc) rarely affecting immunocompetent individuals. ${ }^{2}$ It is characterised by initial erythematous nodule or haemorrhagic bullae which rapidly progresses to form necrotic ulcer which can have a characteristic eschar in the centre surrounded by erythema as seen in our patient. It is most commonly caused by $P$. aeruginosa, however, it can also be caused by other bacteria (Aeromonas, Escherichia coli, Haemophilus influenzae) as well fungi (Candida, Fusarium, Zygomycetes). ${ }^{3}$ Prompt diagnosis and management with empirical antimicrobials (targeting Pseudomonas, eg, cephalosporins, carbapenems, fluoroquinolones), broadspectrum antifungal (like amphotericin) and surgical debridement where feasible are keys to success. Once septicaemia or organ failure ensues, the mortality rises exponentially. ${ }^{4}$

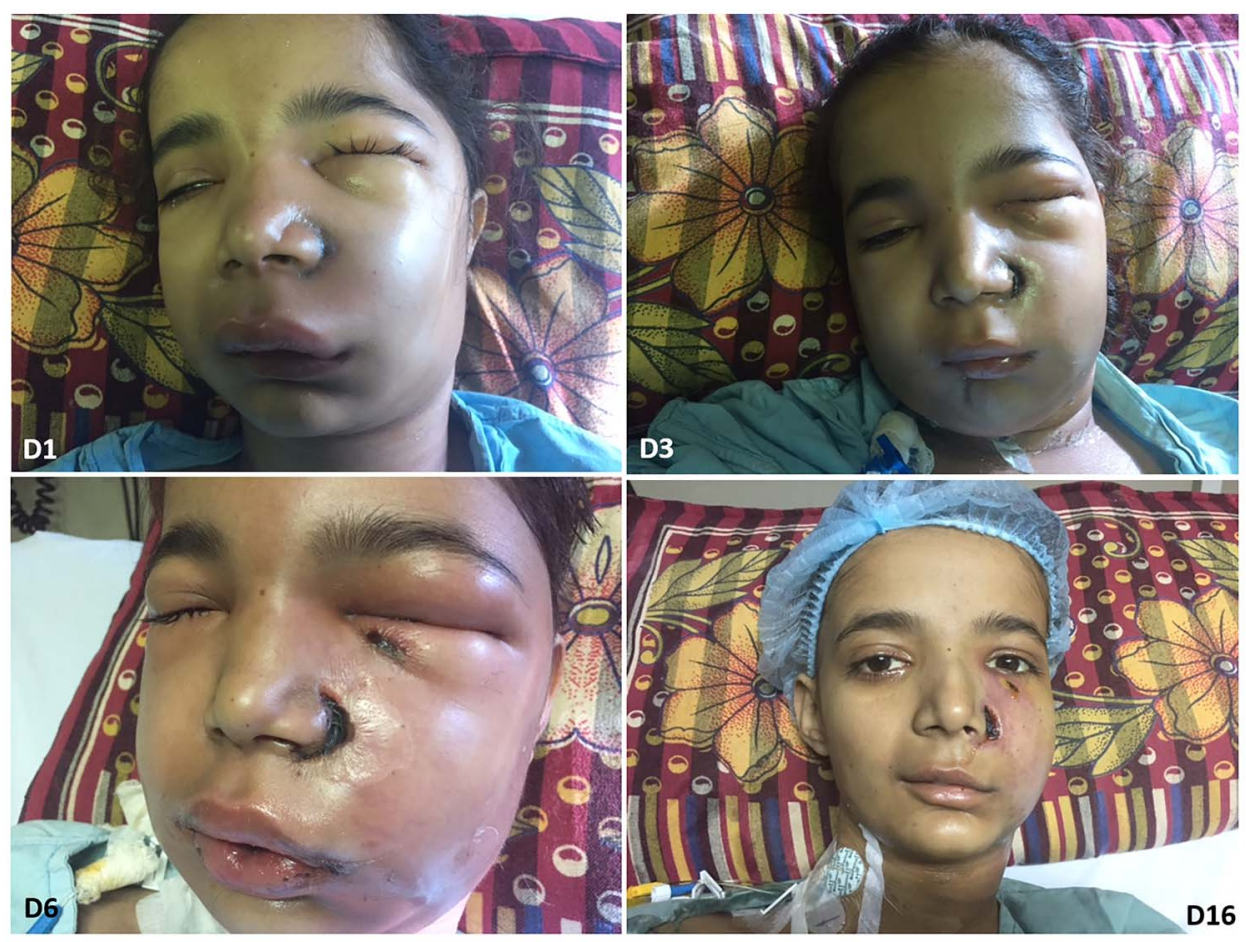

Figure 1 (A) Ecthyma gangrenosum with swelling of the left side of the face with two ulcers of $5 \times 5 \mathrm{~mm}$ along the left border of the nose and another measuring $1 \times 2 \mathrm{~mm}$ below the left eye, with necrosis, erythematous margins on day 1. (B) Progression of the lesions by day 3 as the swelling progressed over the neck and right side of the face. (C) Improvement of patient's lesions after the antibiotic therapy on day 6. (D) Patient's current status at the end of sensitivity guided antibiotic therapy on day 16 of admission. 


\section{Learning points}

Ecthyma gangrenosum is a life-threatening infectious disorder.

- Prompt diagnosis and differentiation from mucormycosis can have implications in therapy and long-term prognosis.

Acknowledgements The authors acknowledge Dr Pallab Ray, Professor, Microbiology Department, for the timely culture of the implicated organism.

Contributors All authors involved in the management of the case. UY drafted the manuscript which was vetted by all authors.
Competing interests None declared.

Patient consent Not obtained.

Provenance and peer review Not commissioned; externally peer reviewed.

\section{REFERENCES}

1 Zhu CY, Zhang GX, Yu ZZ, et al. Pseudomonas aeruginosa ecthyma gangrenosum in a woman with recurrent Graves' disease. Int J Infect Dis 2014;21:19-20.

$2 \mathrm{Koo} \mathrm{SH}$, Lee $\mathrm{JH}$, Shin $\mathrm{H}$, et al. Ecthyma gangrenosum in a previously healthy infant. Arch Plast Surg 2012;39:673-5.

3 Pathak A, Singh P, Yadav Y, et al. Ecthyma gangrenosum in a neonate: not always pseudomonas. BMJ Case Rep 2013;2013:pii: bcr2013009287.

4 De Vos FY, Middelburg TA, Seynaeve C, et al. Ecthyma gangrenosum caused by Pseudomonas aeruginosa in a patient with astrocytoma treated with chemotherapy. Kansenshogaku Zasshi 2014;88(Suppl 9-10):37-9.

Copyright 2017 BMJ Publishing Group. All rights reserved. For permission to reuse any of this content visit

http://group.bmj.com/group/rights-licensing/permissions.

BMJ Case Report Fellows may re-use this article for personal use and teaching without any further permission.

Become a Fellow of BMJ Case Reports today and you can:

- Submit as many cases as you like

- Enjoy fast sympathetic peer review and rapid publication of accepted articles

- Access all the published articles

- Re-use any of the published material for personal use and teaching without further permission

For information on Institutional Fellowships contact consortiasales@bmjgroup.com

Visit casereports.bmj.com for more articles like this and to become a Fellow 